\title{
Effect of irrigation with municipal wastewater on heavy metal and fecal coliform concentrations in plant and soil
}

\author{
Fattahi F. ${ }^{1}$, Daneshvar M. ${ }^{1 *}$, Rahmani H.R. ${ }^{2}$, Modarress Sanavy S.A.M. ${ }^{3}$ and Sami M. ${ }^{4}$ \\ ${ }^{1}$ Department of Agronomy and Plant Breeding, Faculty of Agriculture, Lorestan University, Lorestan, Iran \\ 2Department of Soil and Water Research, Agricultural Research, Educating and Extension Organization, AREEO, Isfahan, Iran \\ ${ }^{3}$ Department of Agronomy and Plant Breeding, Faculty of Agriculture, Tarbiat Modares University, Tehran, Iran \\ ${ }^{4}$ Food Security Research Center and Department of Food Science and Technology, School of Nutrition and Food Science, Isfahan \\ University of Medical Sciences, Isfahan, Iran
}

Received: 09/11/2019, Accepted: 09/12/2019, Available online: 13/12/2019

*to whom all correspondence should be addressed: e-mail: daneshvar.m@lu.ac.ir https://doi.org/10.30955/gnj.003250

\begin{abstract}
In order to investigate the effect of treated wastewater on heavy metals and fecal coliform in plant and soil, a field experiment was conducted in RCBD with three treatments in four replications during 2016-2017 in Borkhar, Isfahan (Iran). Treatments including well water, semi-treated wastewater and combination of well water and wastewater were applied in consecutive cultivation of wheat and forage corn. The amount of heavy metals in the soil did not change after two seasons of wastewater application compared to well water. The amount of fecal coliform in both plants was increased in the irrigation water treatment compared to the well water, which was more evident in the corn plant, which is related to the high moisture content of this plant at harvest stage. Due to the improvement of soil nutrient concentrations after two seasons of continuous application of wastewater and no increase in the amount of heavy metals in the soil, the use of wastewater for agricultural production is permissible. But according to the fecal coliform index, it is recommended not to be used for the production of crops harvested at high humidity and conditions for the survival of pathogens.
\end{abstract}

Keywords: Irrigation, pollution, corn, wheat.

\section{Introduction}

The increasing growth of the world population and especially Iran, the improvement of living standards, in line with the development of agriculture and industry, the occurrence of multiple and subsequent droughts, lack of proper management of water resources and environmental degradation in the last three decades, has caused The exploitation of fresh water resources reaches peak in the whole country, especially in the arid regions. Agriculture is by far the largest consumer of fresh water resources, currently accounting for over 70 per cent of global withdrawals and 86 per cent of the world's total fresh water consumption (FAO, 2012). In Africa and Asia, an estimated 85-90 per cent of all fresh water resources are used for agriculture (UNEP, 2008). Research results reported by Raschid-Sally and Jayacody (2008) indicate that, on a global level, around 200 million farmers use treated, partially treated and untreated wastewater to irrigate their crops, including in areas where irrigation water is heavily polluted. By 2025, a total number of 1.8 billion people will be living in countries or regions with absolute water scarcity. Two-thirds of the world's population could be living under water-stressed conditions, and in Africa alone, it is estimated that 25 countries will be experiencing water stress (UNEP, 2008).

Due to the amount of water resources and per capita consumption, Iran is one of the countries in the group of countries faced with a physical shortage of water. By 2022, more than 10 billion cubic meters of water are expected to be used in urban, rural and industrial areas. With a recycling rate of $60 \%$ to $70 \%$, there will be about 6 to 7 billion cubic meters of water coming from the wastewater and the wastewater will enter the agricultural land (Harati et al., 2011). Irregular water abstraction from groundwater, which reaches about 60 billion cubic meters per year, is another major problem in the country's water sector and has caused irreparable damage to groundwater resources in many parts of the country (Noor, 2017). The limitation of water resources in countries in arid and semi-arid regions is one of the most important problems in the agricultural sector. In addition to its potential benefits, wastewater use also poses high health and environmental risks if no additional measures are applied. Untreated wastewater generated from cities and industries potentially contains a wide range of different constituents, such as pathogens, organic compounds, synthetic chemicals, nutrients, organic matter and heavy metals. The suspended or unsuspended components carried along in the water from different sources affect the water quality (Mateo-Sagasta et al., 2013). These effluents can contain harmful heavy elements that are only 
needed at very low concentrations of the plant. Typically heavy elements include cadmium, chromium, lead and zinc and some other metals that cannot be decomposed by chemical or biological processes in nature, remain unchanged in the soil and enter the organism's food chain (Baldwin and Marshal, 1999). Wastewater has the potential to cause diseases because it contains bacteria, viruses and parasites. Untreated and semi-treated wastewater has a variety of human pathogens. Some of these pathogens are long-lived in the environment and can potentially be transmitted to humans. Survival of pathogens in different environments depends on irrigation methods, high temperature, drying and UV. These factors can lead to faster deaths of pathogens from the surface of the material (Hutchison, et al., 2004).

Coliforms are used as an appropriate microbial indicator to indicate fecal contamination in food and water samples. Among the factors that cause this group of bacteria to be used as a microbial indicator to indicate fecal contamination of water are their natural habitat in the digestive tract of warm-blooded animals, so they are present in the faeces in large numbers. Their durability in water is higher than other pathogenic intestinal bacteria that causes this, Coliforms can also be present when waterborne intestinal bacteria are present. There is no significant proliferation in water.
Wastewater is one of the most unusual water resources and its application in agriculture requires special management that, while optimally utilizing it, does not pose environmental and health risks to soil, plants and surface and groundwater resources. The purpose of this study was to investigate the effects of semi-treated wastewater on heavy metals in soil and fecal coliforms in different plant components on wheat and forage maize rotation in a land plot in Borkhar, Isfahan (Iran).

\section{Materials and methods}

This research was conducted during 2016-2017 in a plot of 1000 square meters in the Dolatabad area of Isfahan province. It is located in $32^{\circ} 48^{\prime} \mathrm{N}$ latitude and $51^{\circ} 44^{\prime} \mathrm{E}$ longitude and $1560 \mathrm{~m}$ Altitude from sea level with dry climate. In order to determine the chemical and physical properties of the soil, four soil samples were collected and sent to the Laboratory of Soil and Water Research Center of Isfahan Agricultural and Natural Resources Research Center. These samples were also analyzed for standard physic-chemical properties. The soil samples were air-dried and ground to pass a $2 \mathrm{~mm}$ sieve size, and then extracted using a solution of DTPA (0.05 mol/l) contains $\mathrm{CaCl} 2(0.01$ $\mathrm{mol} / \mathrm{l}$ ) in $\mathrm{pH}$ of 7.3 (Lindsay and Norvell, 1978). The extractable DTPA-Pb, $\mathrm{Cu}, \mathrm{Fe}, \mathrm{Cd}, \mathrm{Ni}, \mathrm{Cu}$, and $\mathrm{Zn}$ were determined by atomic absorption method. Physical and chemical properties of soil in experimental field were presented in Table 1.

Table 1 Physical and chemical characteristics of the tested soil

\begin{tabular}{|c|c|c|c|c|c|c|c|c|c|c|c|c|c|}
\hline \multirow{2}{*}{ Soil texture } & \multirow{2}{*}{$(E C)\left(d S m^{-1}\right)$} & \multirow{2}{*}{$\mathrm{pH}(1: 2)$} & N-total & OC & $\mathbf{P}$ & $\mathrm{K}$ & $\mathrm{Cu}$ & $\mathrm{Zn}$ & $M n$ & $\mathrm{Fe}$ & $\mathbf{N i}$ & $\mathrm{Cd}$ & $\mathrm{Pb}$ \\
\hline & & & \multicolumn{2}{|c|}{ (\%) } & \multicolumn{9}{|c|}{$\left(\mathrm{mg} \mathrm{kg}^{-1}\right)$} \\
\hline Silty clay & 4.4 & 7.52 & 0.05 & 0.51 & 1.45 & 319 & 1.12 & 0.72 & 4.36 & 13.8 & 0.76 & 0.06 & 1.8 \\
\hline
\end{tabular}

Experimental design was a randomized complete blocks with four replicates. The irrigation treatments were: well water in as a control treatment (T1); irrigation with treated municipal wastewater (T2). $50 \%$ well water and $50 \%$ treated municipal wastewater (T3). Quality of well water and treated wastewater are shown in Table 2.

Table 2 Water analysis of the well water and wastewater

\begin{tabular}{|c|c|c|c|c|c|c|c|c|c|c|c|c|c|}
\hline & $E C * 10^{6}$ & $\mathrm{pH}$ & TDS & N-NH4 & N-NO3 & $\mathbf{P}$ & K & $\mathrm{Mn}$ & $\mathrm{Fe}$ & $\mathrm{Zn}$ & $\mathrm{Pb}$ & $\mathrm{Cd}$ & $\mathrm{Cr}$ \\
\hline & $\mu S \mathrm{~cm}-1$ & & \multicolumn{11}{|c|}{ (mg L-1) } \\
\hline Well water & 3.36 & 7.7 & 2150 & 0 & 2.4 & 0.12 & 6.7 & 0.08 & 0.01 & 0.01 & 0.02 & 0.01 & 0.01 \\
\hline Waste water & 1.70 & 7.2 & 1088 & 46 & 7.80 & 5.8 & 11.9 & 0.07 & 0.06 & 0.05 & 0.02 & 0.01 & 0.01 \\
\hline
\end{tabular}

According to the results of soil analysis, $300 \mathrm{~kg} \mathrm{ha}^{-1}$ of superphosphate fertilizer was mixed with secondary soil tillage. Nitrogen fertilizer required by urea fertilizer was fed on two planting and stemming times of $250 \mathrm{~kg} \mathrm{ha}^{-1}$. Experiment plots were seeded with Roshan cultivar with 20 $\mathrm{cm}$ row to row distance and $2 \mathrm{~cm}$ between plants. Wheat seeds was planted manually in October 2016. Seeds were sown $4 \mathrm{~cm}$ deep. There was $4 \mathrm{~m}$ distance between plots to prevent of water leakage. All operations were done regularly during the growing season. Weeds were removed by hand. After planting, irrigation was applied as required during the growing season. The wheat was harvested in June 2017. For measurement of plant characteristics two edge rows eliminated as margin effects and two square meter of each plot was used for sampling. Data collected (Obtained by combining the four center rows at each experiment unit) included: grain yield, 1000-grain weight, number of grain per ear, grain and straw $\mathrm{N}, \mathrm{P}$ and $\mathrm{K}$ content. Soil samples were collected randomly after harvesting from different each experiment unit and analyzed for $\mathrm{N}, \mathrm{P}, \mathrm{K}, \mathrm{Cd}, \mathrm{Pb}$ and $\mathrm{Ni}$. After wheat harvest, the experiment units were plowed again and prepared for corn planting. Corn seeds was planted manually in June 2017. Sowing was done as rows in $70 \mathrm{~cm}$ wide rows with $15 \mathrm{~cm}$ spacing within-rows with six rows per plot by Single Cross 704 cultivar. By reaching the soft dough stage, it was taken to sample and sent to the laboratory to measure the traits. Fresh forage weight (yield), ear, stalk and leaf fresh weight, grain and mix stem leaf N, P and K content were measured. after forage corn harvest, Soil samples were collected randomly after harvesting forage corn from different each experiment unit and analyzed for $\mathrm{N}, \mathrm{P}, \mathrm{K}, \mathrm{Cd}, \mathrm{Pb}$ and $\mathrm{Ni}$. For 
plant analysis, after harvesting each plant and drying their plant samples (in the oven for 48 hours and $70^{\circ} \mathrm{C}$ ), the total nitrogen concentration in the seeds, stems and leaves was determined by the Kjeldahl method (Bremner, 1996), To determine phosphorus in plant samples, The colorimetric method was performed at a wavelength of $470 \mathrm{~nm}$ using a spectrophotometer. Potassium of the plant organs was performed using flame photometric method (Waling et al., 1989). For bacterial analysis of the plant, at the end of the growing season and after the final irrigation of the plots, by dropping the side rows of each plot as marginal rows, plants were randomly selected from the middle of the plot and Leaf, stem and seed samples were collected in four replications and the bacteria were counted by MPN method (APHA, 2005). Statistical analysis was performed using SAS statistical software. Means were compared by using the least significant difference of Fisher LSD method at $5 \%$ probability level.

\section{Results and discussion}

\subsection{Macronutrients and heavy metal}

After harvesting wheat and corn, soil nitrogen, phosphorus and potassium concentrations were measured in all three irrigation treatments. The effect of water treatment on the amount of residual phosphorus in soil after wheat harvest was significant at $5 \%$ probability level but it was not significant on soil nitrogen and potassium content (Table 5). Mean comparison results showed that the amount of residual phosphorus in soil after wheat and maize harvest increased by $29 \%$ and $85 \%$, respectively, as compared to control treatment but the amount of soil nitrogen and potassium after wheat harvest was not affected by treatments. Also Mean comparison results showed that the amount of nitrogen and potassium in soil after corn increased by $28 \%$ and $11 \%$, respectively. The amounts of heavy metals including cadmium, lead and chromium in soil were measured in all three irrigation water treatments after wheat and maize harvest. The effect of irrigation treatment on the concentration of each of the above heavy metals in the soil after wheat harvest and maize was not significant at $5 \%$ probability level (Table 5) and there was no statistically significant difference between the results of the mean comparison of these elements in thesoil (Table 3).

Table 3 The effect of irrigation treatments on nutrient and heavy metals content in soil after wheat and corn harvesting

\begin{tabular}{|c|c|c|c|c|c|c|}
\hline \multicolumn{7}{|c|}{ Wheat } \\
\hline Treatments & Total nitrogen (\%) & Phosphorus (mg kg ${ }^{-1}$ ) & Potassium (mg kg ${ }^{-1}$ ) & Chrome (mg kg-1) & Lead $\left(\mathrm{mg} \mathrm{kg}^{-1}\right)$ & Cadmium (mg kg-1) \\
\hline Well water & $0.035 \mathrm{a}$ & $5.175 b$ & $362.5 \mathrm{a}$ & $0.107 \mathrm{a}$ & $1.340 \mathrm{a}$ & $0.04 \mathrm{a}$ \\
\hline Wastewater & $0.040 \mathrm{a}$ & $6.700 \mathrm{a}$ & $396.5 \mathrm{a}$ & $0.105 \mathrm{a}$ & $1.345 \mathrm{a}$ & $0.03 \mathrm{a}$ \\
\hline Alternate & $0.035 \mathrm{a}$ & $5.250 \mathrm{~b}$ & $385.5 \mathrm{a}$ & $0.105 \mathrm{a}$ & $1.330 \mathrm{a}$ & $0.04 \mathrm{a}$ \\
\hline \multicolumn{7}{|c|}{ Corn } \\
\hline Treatments & Total nitrogen (\%) & Phosphorus $\left(\mathrm{mg} \mathrm{kg}^{-1}\right)$ & Potassium (mg kg-1) & Chrome (mg kg-1) & Lead $\left(\mathrm{mg} \mathrm{kg}^{-1}\right)$ & Cadmium (mg kg-1) \\
\hline Well water & $0.052 \mathrm{~b}$ & $1.97 \mathrm{~b}$ & $354.7 \mathrm{~b}$ & $0.102 \mathrm{a}$ & $0.915 \mathrm{a}$ & $0.040 \mathrm{a}$ \\
\hline Wastewater & $0.067 \mathrm{a}$ & $3.65 \mathrm{a}$ & $393.7 \mathrm{a}$ & $0.102 \mathrm{a}$ & $0.997 \mathrm{a}$ & $0.040 \mathrm{a}$ \\
\hline Alternate & $0.060 \mathrm{ab}$ & $2.95 \mathrm{a}$ & $388.2 \mathrm{ab}$ & $0.112 \mathrm{a}$ & $1.055 \mathrm{a}$ & $0.040 \mathrm{a}$ \\
\hline
\end{tabular}

Means with different letters on the same column are significantly different $(P<0.05)$ based on LSD test.

Use of wastewater in irrigation, firstly it is important to supply water in arid areas and secondly to supply some of the plant nutrients needed. It should be noted that due to wheat cultivation, less water is used to complete the plant life than maize cultivation, which affects the total amount of water entering the soil and nutrients entering the soil, On the other hand in corn cultivation, treatments were similarly applied to the same plots of the first experiment and this may affect the amount of nitrogen input to the soil. In a study, increased levels of nitrogen, potassium, and phosphorus in rapeseed were reported in treatments irrigated with effluent compared to the control, which could provide part of the plant's nutritional requirement (Mozafari et al., 2013). What is certain is that many wastewater alone cannot meet the nutritional requirements of plants for high levels of nutrients, including nitrogen. Therefore, in such cases, their application with appropriate amounts of chemical fertilizers to meet the plant's nutritional needs should be considered (Sommers et al., 1976). On the other hand, the results also showed no significant difference between potassium and phosphorus concentrations in wastewater and well water treatments (Nazari et al., 2006). Lack of nutrients in sufficient concentrations in wastewater and soil, element type, short time to accumulate sufficient amount of wastewater elements in soil, plant factors and soil characteristics, including $\mathrm{pH}$ and Soil adsorption it affects the accumulation of elements in the soil.

Similar results have been observed by other researchers in the field, In India, irrigation with wastewater increased the amount of macro nutrients (nitrogen, potassium) and soil organic carbon, and yield of wheat was higher than that of ordinary irrigated plots (Singh et al., 2012). The results of Alimohammadi's research (2015) also showed that the amount of macro phosphorus and potassium at $0-30 \mathrm{~cm}$ depth of soil increased for 3 years in wastewater treatment compared to normal water (control) in alfalfa cultivation, but the amount of soil nitrogen was not significantly different (Alimohammadi, 2015). The 
results of this and other experiments show that the use of municipal wastewater is effective on the amount of macro nutrients in the soil and increases the entry of these elements into the soil. This increase is primarily due to the higher concentration of nutrients in the effluent than the well water and secondly to the effluent characteristics such as $\mathrm{pH}$ and lower sodium content, which makes the effluent irrigation superior to the well water and provides part of the plant nutrient requirement (Table 2). Increasing the duration of application and the amount of effluent in a soil has the effect of increasing the amount of nutrients in the soil.

In this experiment, an increase in the amount of soil nutrients in corn was more pronounced than the wheat because of the greater amount of effluent consumed and the duration of use. This subject shows, these properties can be effective in reducing the consumption of macro fertilizers.

There are numerous studies on the use of wastewater as a source of agricultural water supply And sometimes different results are observed, for example In a 7-year study, the use of municipal wastewater did not change the concentrations of iron, copper, manganese, nickel, and lead (Safari Sanjani, 1995). In contrast, a 50-year study showed that irrigation with effluent had a significant increase in the concentration of cadmium, lead, nickel, zinc and copper relative to the reference soil (irrigated with well water) (Chen et al., 2009). Lead is one of the most important pollutants, and many researchers believe that alkaline soil can prevent toxicity (loannis and Prodromos, 2009). Therefore, soil $\mathrm{pH}$ affects the solubility and transport of heavy metals. Munir et al. (2006) reported that irrigation of forage plants with municipal wastewater for 2 to 10 years increased the concentration of zinc, copper, iron and manganese in the soil. Any change in the concentration of any metal in the soil is a function of the concentration of the metal in the effluent (which depends on the origin of the effluent), the amount of effluent used, the plant harvest and sometimes the leaching. Long-term use of industrial wastewater in irrigation can lead to heavy metal accumulation in soils and plants. According to the results of the concentration table of the above elements in the effluent of the municipal treatment plant, the concentration of heavy elements is generally very low (Table 2). On the other hand, the period of effluent use in this experiment was short-lived. In other studies that have chosen long-term time frames, there has been a general shift in the concentration of these elements in the soil. Based on the results of this experiment, it can be recommended to use municipal wastewater in short or medium term with proper management for irrigation.

\subsection{Fecal coliform in plant}

The amount of fecal coliform in wheat grain and straw, leaf and stem (lower and middle part of stem) Corn was measured in three treatments. Analysis of variance showed that the effect of irrigation water treatment on fecal coliform in wheat (grain and straw) and maize (leaf, stem and grain) organs was significant at $5 \%$ probability level (Tables 5). The highest amount of fecal coliform in wheat straw and grain was obtained in wastewater and intermittent irrigation treatments respectively. The highest amount fecal coliforms of corn grain and leaf obtained in wastewater and intermittent irrigation treatments respectively and the lowest amount was obtained in well water treatment (Table 4). Since the stem is in direct contact with the effluent, in maize, samples were collected from middle and lower stem and the highest amount of fecal coliforms was observed in wastewater and intermittent irrigation treatments in the lower stem samples compared to the middle stem.

As mentioned, Wastewater treatment to well water increased the amount of fecal coliform in wheat and forage maize plant samples, The important point here is that the higher the amount of coliform in corn samples than wheat, which may depend on the amount of moisture in the organs of this plant, Because forage maize generally has a high moisture content at harvest, but wheat samples have a very low moisture content at harvest stage.

The presence of moisture is one of the important factors in the survival of these microscopic organisms and the use of effluent to produce green forage such as forage maize is not recommended due to high moisture content in plant organs, But in the case of wheat, factors such as the interval between harvest to consumption, exposure to sunlight for longer periods, and high temperatures at harvest time can reduce the microbial load. It should be noted, that wind or animal manure can also transmit fecal coliforms to aerial organs, especially leaves and stems, but the seed generally grows within a certain cover and is less susceptible to contamination.

Other studies have found similar results. For example, the amount of lactose-positive bacteria, total and fecal coliforms of old leaves were higher than new leaves, which could be due to the proximity of old leaves to the ground and their potential to be further contaminated with effluent during irrigation (Alinezhadian et al., 2012).

In this experiment, maize stem samples obtained from the lower part of the plant showed more coliform than the upper part of the stem. The direct contact of the wastewater with the lower parts of the maize stem, lack of direct light irradiation and higher relative humidity inside the canopy seems to be the result. Survival of pathogens in different environment depends on the tissues moisture content, irrigation systems, high temperature and ultralight. These factors can lead to the death of pathogens agents (Hutchison et al., 2004). Some researchers suggest that non-crude products or their moisture content are low when consumed and it's a long time from harvest to consumption, wastewater can be used for irrigation. Pathogens are mostly transmitted to root crops such as radishes, lettuce and other vegetables in the soil environment, jeopardizing the health of the food, especially when consumed by crude consumers, but for cereal crops, the use of effluent creates less problems (Natvig et al., 2002). 
Table 4 The effect of irrigation treatments on nutrient and heavy metals content in soil after wheat and corn harvesting

\begin{tabular}{|c|c|c|c|c|}
\hline Treatments & Fecal coliform (stalk Middle) (CFU) & Fecal coliform (stalk down) (CFU) & Fecal coliform (corn leaf) (CFU) & Fecal coliform (corn grain) (CFU) \\
\hline Well water & $1685 \mathrm{~b}$ & $4075 \mathrm{c}$ & $7275 c$ & $2.5 \mathrm{c}$ \\
\hline Wastewater & 13025 a & 30500 a & 22600 a & $1100 \mathrm{a}$ \\
\hline Alternate & $11400 \mathrm{a}$ & $10275 b$ & $15100 \mathrm{~b}$ & $592 b$ \\
\hline Treatments & Fecal coliform (Wheat grain) (CFU) & Fecal coliform (Wheat straw) (CFU) & & \\
\hline Well water & $\mathrm{OB}$ & $1300 \mathrm{c}$ & & \\
\hline Wastewater & $2.5 \mathrm{a}$ & 5577 a & & \\
\hline Alternate & $2.5 \mathrm{a}$ & $2227 \mathrm{~b}$ & & \\
\hline
\end{tabular}

Means with different letters on the same column are significantly different $(P<0.05)$ based on LSD test.

Table 5 The results of variance analysis of the effect of irrigation treatments on soil and fecal coliform

(Mean of square)

\begin{tabular}{|c|c|c|c|c|c|c|c|}
\hline \multirow[b]{2}{*}{ S.V } & \multicolumn{7}{|c|}{ Soil samples after wheat harvesting } \\
\hline & $D f$ & Total Nitrogen & Phosphorus & Potassium & Cadmium & Chrome & Lead \\
\hline Block & 3 & 0.00006 & 0.347 & 834.6 & 0.00009 & 0.0012 & 0.0033 \\
\hline Treatments & 2 & 0.00003 & $2.955^{*}$ & 1196.3 & 0.0001 & 0.0000 & 0.0002 \\
\hline Error & 6 & 0.00003 & 0.3691 & 556.33 & 0.0006 & 0.0003 & 0.0044 \\
\hline \multirow[t]{2}{*}{ CV (\%) } & & 15.74 & 10.64 & 6.185 & 18.181 & 16.59 & 4.987 \\
\hline & & \multicolumn{6}{|c|}{ Soil samples after corn harvesting } \\
\hline S.V & $D f$ & Total Nitrogen & Phosphorus & Potassium & Cadmium & Chrome & Lead \\
\hline Block & 3 & 0.00002 & 0.412 & 71.63 & 0.00009 & 0.00004 & 0.0128 \\
\hline Treatments & 2 & 0.0002 & $2.822^{*}$ & 1782.3 & 0.0001 & 0.00013 & 0.0198 \\
\hline Error & 6 & 0.00004 & 0.298 & 503.22 & 0.0006 & 0.00004 & 0.0082 \\
\hline \multirow[t]{2}{*}{ CV (\%) } & & 11.453 & 19.155 & 5.920 & 18.181 & 18.181 & 9.196 \\
\hline & & \multicolumn{2}{|c|}{ Wheat samples } & \multicolumn{4}{|c|}{ Corn samples } \\
\hline S.V & $D f$ & Fecal coliform (Wheat grain) & $\begin{array}{c}\text { Fecal coliform (Wheat } \\
\text { straw) }\end{array}$ & Fecal coliform (corn grain) & Fecal coliform (corn leaf) & $\begin{array}{c}\text { Fecal coliform (stalk } \\
\text { down) }\end{array}$ & Fecal coliform (stalk Middle) \\
\hline Block & 3 & 0.0022 & 250544.4 & 1860.8 & 2598888 & 616667 & 216577 \\
\hline Treatments & 2 & $8.333^{*}$ & $20253175^{*}$ & $1206775 * *$ & $235663333^{* *}$ & $763847500 * *$ & $150411633^{* *}$ \\
\hline Error & 6 & 0.0055 & 211952.7 & 2015.8 & 778888 & 734167 & 1941411 \\
\hline CV (\%) & & 4.472 & 15.16 & 7.946 & 5.890 & 5.731 & 16.009 \\
\hline
\end{tabular}

$n s,{ }^{*}$ and ${ }^{* *}$ are not significant, significant at $5 \%$ and $1 \%$ level of probability, respectively. 


\section{Conclusion}

Although the use of wastewater treatment plant as one of the available but unusual water resources has a decadeslong history, this issue has always been associated with concerns about heavy metals entering the soil and plant and microbial contamination. The results of this experiment showed when using wastewater in agriculture, to the concentration of metals in wastewater and the origin of the treated wastewater from an urban or industrial point of view should be considered. In this experiment, the effluent was from municipal sewage that the concentration of heavy metals in the output was generally low, and the results of its application in two consecutive cultivations of wheat and maize showed that it did not increase the concentration of harmful heavy metals in the soil and no effect of soil contamination to heavy metals was observed. Wastewater application can help increase the concentration of plant nutrients in soil and plants and improve plant performance and increase production per unit area. On the other hand, due to the high moisture content of the forage maize at the time of harvest, the use of effluent for the production of forage from maize is not recommended at all. Urban wastewater can also be a sustainable source of water for agriculture, especially in arid and low-water areas and it provided part of the country's water demand for crops with low moisture content when consumed and harvested with using comprehensive management in the country.

\section{References}

Alimohammadi R. (2015), Changes in soil and plant due to irrigation with treated domestic wastewater and its effects on alfalfa yield, Journal of Water Research in Agriculture, 29(1), 35-47.

Alinezhadian A., Karimi A., Mohammadi J., Nikookhah F. and Anderson M.N. (2012), Study of soil bacterial and crop quality irrigated with treated municipal wastewater, Iranian Journal of Health and Environment, 6(3), 365-376.

APHA. (2005), Standard Methods for the Examination of Water and Wastewater, 21st Edition, Washington D.C: American Public Health Association/American Water Works Association/Water Environment Federation.

Baldwin D.R. and Marshal W.J. (1999), Heavy metal poisoning and its laboratory investigation, Annals of Clinical Biochemistry, 36(3) 267-300.

Bremner J.M. (1996), Nitrogen total. Methods of soil analysis. Part 3. Chemical methods, SSSA Book Ser. SSSA and ASA, Madison, USA.

Chen Z.F., Zhao Y., Zhu Y., Yang X., Qiao J., Tianc Q. and Zhang Q. (2009), Health risks of heavy metals in sewage-irrigated soils and edible seeds in Langfang of Hebei province, China, Journal of Science Food Agriculture, 90, 314-320.

Food and Agriculture Organization of the United Nations (FAO) (2012), Coping with water scarcity: An action framework for agriculture and food security. FAO Water Reports, No. 38. Rome. Available from www.fao.org/docrep/016/i3015e/ i3015e.pdf.

Harati M., Varavi pour M., Tamadon Rastegar M. and Foghi B. (2011), Effect of urban wastewater usage and problems of accumulation of heavy metals in agricultural lands (south of Tehran), African Journal of Agricultural Research, 6(14), 32243231.
Hutchison M.L., Walters L.D., Moore A., Crookes K.M. and Avery S.M. (2004), Length of time before incorporation on survival of pathogenic bacteria present in livestock wastes applied to agricultural soil, Journal of Applied and Environmental Microbiology, 70, 115-118.

Ioannis K.K. and Prodromos H.K. (2009), Distribution of elemental interactions in Brussels sprouts plants, under the treated municipal wastewater, Journal of Plant Interactions, 4, 219231.

Lindsay W.L. and Norvell W.A. (1978), Development of a DTPA soil test for zinc, iron, manganese, and copper, Soil Science Society of America Journal, 42, 421-428.

Mateo-Sagasta J., Medlicott K., Qadir M., Raschid-Sally L., Drechsel P. and Liebe J. (2013), Proceedings of the UN-Water project on the Safe Use of Wastewater in Agriculture, Bonn, Germany: UNW-DPC.

Mozafari H., Shirani Rad A.H. and Jahanfar D. (2013), Evaluation of some minerals and heavy metals in canola, alfalfa and spinach after irrigation with varying degrees of domestic wastewater, Food Technology \& Nutrition, 10(4), 45-54.

Munir J., Rusan M., Hinnawi S. and Rousan L. (2006), Long term effect of wastewater irrigation of forage crops on soil plant quality parameters, International conference on sustainable water management, rational water use, wastewater treatment and reuse, Marrakech, Morocco, 8-10 Jun.

Natvig E.E., Ingham S.G., Ingham B.H., Cooperband L.R. and Roper T.R. (2002), Salmonella enterica Serovar Typhimurium and Escherichia coli contamination of root and leaf vegetables grown in soils with incorporated bovine manure, Journal of Applied and Environmental Microbiology, 68(6), 2737-2744.

Nazari M.A., Shariatmadari H., Afyuni M., Mobli M. and Rahili S.H. (2006), Effect of Industrial Sewage-Sludge and Effluents Application on Concentration of Some Elements and Dry Matter Yield of Wheat, Barley and Corn, Journal of Water and Soil Science, 10(3), 97-111.

Noor H. (2017), Analysis of Groundwater Resources Utilization and Their Current Condition in Iran, Journal of Rainwater Catchment Systems, 5(2), 29-38.

Raschid-Sally L. and Priyantha J. (2008), Drivers and characteristics of wastewater agriculture in developing countries: Results from a global assessment, International Water Management Institute, (IWMI Research Report 127), Colombo, Sri Lanka.

Safari Sajani A.A. (1995), Effect of irrigation with wastewater on some soil chemical properties of Isfahan Borkhar area and accumulation of some elements in alfalfa, Thesis of Master Science, Isfahan University of Technology.

Singh P.K., Deshbhratar P.B. and Ramteke D.S. (2012), Effects of sewage wastewater irrigation on soil properties yield and environment, Agricultural water management, 103, 100-104.

Sommers L.E., Nelson D.W. and Yost K.J. (1976), Variable nature of chemical composition of sewage sludge, Journal of Environmental Quality, 5(3), 303-306.

United Nations Environment Programme (UNEP). (2008), Vital Water Graphics - An Overview of the State of the World's Fresh and Marine Waters, 2nd Edition, Nairobi, Kenya: UNEP.

Waling I., Vark W.V., Houba V.J.G. and Vanderlee J.J. (1989), Soil and Plant Analysis, a series of syllabi. Part 7. Plant Analysis Procedures, Netherland: Wageningen Agriculture University. 